\title{
Current Limiter Device
}

National Cancer Institute

\section{Source}

National Cancer Institute. Current Limiter Device. NCI Thesaurus. Code C49902.

A device designed to maintain a current at a specified level regardless of other

fluctuations in the system. 